University of Nebraska - Lincoln

DigitalCommons@University of Nebraska - Lincoln

NASA Publications

National Aeronautics and Space Administration

2-2008

\title{
Food Security Under Climate Change
}

Molly E. Brown

NASA Goddard Space Flight Center Biospheric Sciences Branch, molly.brown@nasa.gov

Chris C. Funk

University of California - Berkeley, chris@geog.ucsb.edu

Follow this and additional works at: https://digitalcommons.unl.edu/nasapub

Brown, Molly E. and Funk, Chris C., "Food Security Under Climate Change" (2008). NASA Publications. 131.

https://digitalcommons.unl.edu/nasapub/131

This Article is brought to you for free and open access by the National Aeronautics and Space Administration at DigitalCommons@University of Nebraska - Lincoln. It has been accepted for inclusion in NASA Publications by an authorized administrator of DigitalCommons@University of Nebraska - Lincoln. 


\section{Food Security Under Climate Change}

\section{Molly E. Brown and Christopher C. Funk}

$\mathrm{S}$ ome of the most profound and direct impacts of climate change over the next few decades will be on agricultural and food systems. On page 607 of this issue, Lobell et al. (1) show that increasing temperatures and declining precipitation over semiarid regions are likely to reduce yields for corn, wheat, rice, and other primary crops in the next two decades. These changes could have a substantial impact on global food security.

M. E. Brown is at Science Systems and Applications, Inc. NASA Goddard Space Flight Center Biospheric Sciences Branch, Code 614.4, Greenbelt, MD 20771, USA. C. C. Funk is in the Climate Hazard Group, Geography Department, University of California, Santa Barbara, CA, 93106, USA. E-mail: molly.brown@nasa.gov; chris@ geog.ucsb.edu
Since the 1990s, rising commodity prices and declining per capita cultivated area have led to decreases in food production, eroding food security in many communities (2). Many regions that lack food security rely on local agricultural production to meet their food needs. Primarily tropical and subtropical, these regions are substantially affected by both global climate variations and global commodity price fluctuations. Warming in the Indian Ocean (3) and an increasingly "El Nino-like" climate (4) could reduce main-season precipitation across parts of the Americas, Africa, and Asia (see the figure).

In food-insecure regions, many farmers both consume their product and sell it in local markets. This exposes farmers to climate vari-
Food insecurity is likely to increase under climate change, unless early warning systems and development programs are used more effectively.

ations, because when they produce less their income goes down while their costs go up to maintain basic consumption. Large-scale hunger can ensue, even when there is sufficient food in the market that has been imported from elsewhere.

National revenue can also be affected by large-scale droughts, which restrict the ability of countries with small budgets to purchase grain on the international market. Thus, recent large increases in grain prices reduce access to food for the poor, for example, in Tanzania, who compete for corn with ethanol producers and hog farmers in the United States. Finally, up to half of all malnutrition is driven by nonfood factors through diseases such as HIV/AIDS and malaria; the latter disease is 


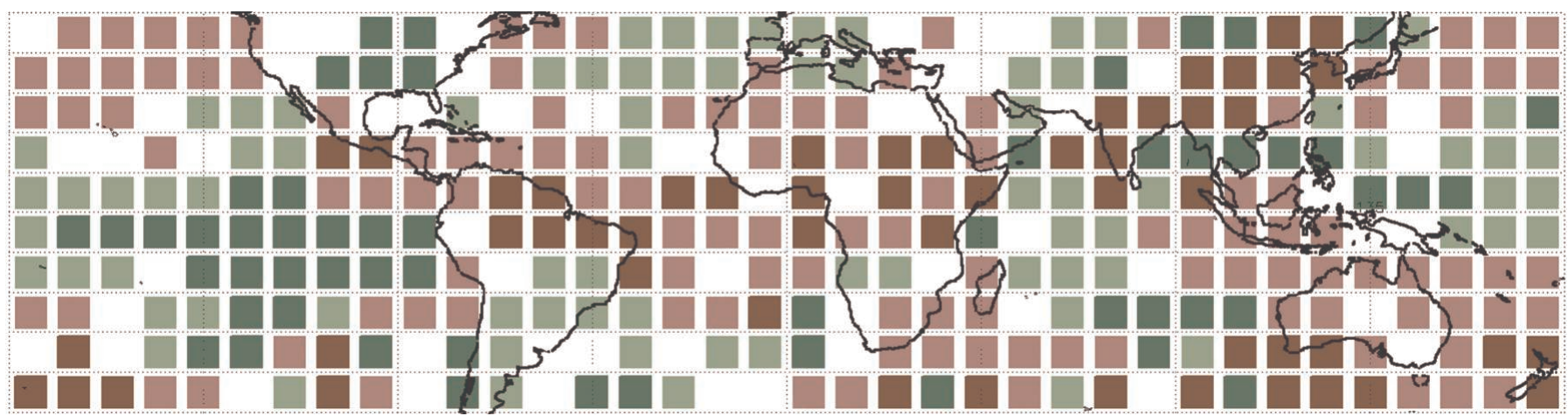

Upcoming change. Each $10^{\circ}$ grid cell in this map shows the anticipated impact of warming in the Indian (3) and eastern Pacific (4) Oceans, expressed as a shift in standardized precipitation, $\Delta \mathrm{P}$, in the dominant 3-month season (8). $\sigma$ is the standard deviation. Several regions where precipitation is likely to change over the next 50 years—such as eastern and southern Africa-already face significant food security problems.

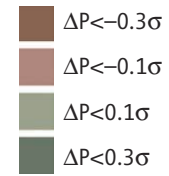

likely to become more severe and widespread with warming temperatures.

Lobell et al. use crop models to calculate changes in agricultural production to 2030. The results show that climate change is likely to reduce agricultural production, thus reducing food availability. Identifying the impact of this reduced production will, however, be complicated by other changes. The latter include rising oil prices, the globalization of the grain market, and a structural change in demand for key food supplies due to increasing demand for biofuels and rising per-capita consumption in India and China. These changes have pushed up supply costs for staple foods by $40 \%$ or more in many food-insecure areas. Decoupling these effects to implement mitigation and adaptation programs will be difficult.

Climate change impacts on farmers will vary by region, depending on their use of technology. Technological sophistication determines a farm's productivity far more than its climatic and agricultural endowments. Food insecurity, therefore, is not solely a product of "climatic determinism" and can be addressed by improvements in economic, political, and agricultural policies at local and global scales. In currently food-insecure regions, farming is typically conducted manually, using a hoe and planting stick with few inputs. The difference between the productivity of these farms and those using petroleum-based fertilizer and pesticides, biotechnology-enhanced plant varieties, and mechanization is extreme (5). Not only will climate change have a differential effect on ecosystems in the tropics due to their already warmer climates, but also poor farmers in the tropics will be less able to cope with changes in climate because they have far fewer options in their agricultural system to begin with. These handicaps can be exacerbated by macro-economic policies that create disincentives for agricultural development, such as agricultural subsidies in the United States and Europe and poorly implemented cash transfer programs (6).

The study by Lobell et al. suggests that communities can cope with climate change, for example, by switching from producing corn to producing sorghum, whose lower water requirements and higher temperature tolerances are better suited to a warmer and drier climate. However, this adaptation measure may be impossible to implement in many parts of the developing world. For example, it assumes markets for millet in regions where only maize is eaten, and technology and know-how about how to process and consume sorghum in maize zones. Communities may nevertheless be forced, as they are today, to consume what they produce regardless of cultural preferences.

Today, millions of hungry people subsist on what they produce. If climate change reduced production while populations increase, there is likely to be more hunger. However, it may still be possible to reduce world hunger through programs that feed the poor during crises and by investing in agricultural inputs such as fertilizer and improved varieties that can dramatically increase yields (2). Improved environmental monitoring and prediction systems can provide more effective early warnings, which may help governments to take action to preserve the thin agriculture production margins by which many make ends meet (7). Early warning systems involve extensive climate monitoring and prediction tools that could be used to enhance agricultural development programs. Crop insurance programs that are triggered by remote sensing data products may ensure farmer's livelihoods even in drought years. Investments in improved seeds and varietals and an augmented use of inorganic fertilizer $(2,6)$ can increase yields. Improved local governance, reduced developed-world agricul- tural subsidies, and more nuanced food aid policies that protect local markets could together produce rapid improvements in food access and availability, reducing hunger while providing for more people.

$30 \%$ of farmers in developing countries are food-insecure; the work of Lobell et al. suggests that climate change may impact these undernourished communities by decreasing local yields while contributing to a global increase in commodity prices through significant global reduction in the production of corn, wheat, and rice. Despite these challenges, the very low agricultural productivity of food-insecure countries presents a great opportunity. Transform these agricultural systems through improved seed, fertilizer, land use, and governance, and food security may be attained by all.

\section{References and Notes}

1. D. B. Lobell et al., Science 319, 607 (2008).

2. Food and Agricultural Organization, The State of Food and Agriculture, 2007.

3. J. Verdin, C. C. Funk, G. Senay, R. Choularton, Philos. Trans. R. Soc. B 360, 2155 (2005).

4. S. Solomon et al., Climate Change 2007: The Physical Science Basis. Contribution of Working Group I to the Fourth Assessment Report of the IPCC (Cambridge Univ. Press, Cambridge, UK, 2007).

5. C. Thirtle, L. Lin, ]. Piesse, World Develop. 31, 1959 (2003).

6. OXFAM, Causing Hunger: An Overview of the Food Crisis in Africa, OXFAM briefing paper, July 2006; www.oxfam. org.uk/what_we_do/issues/conflict_disasters/bp91_ hunger.htm.

7. M. E. Brown, C. C. Funk, G. Galu, R. Choularton, EOS, Trans. Am. Geophys. Union 88, 381 (2007).

8. The figure shows statistically reformulated $(7) \mathrm{CO}_{2}$ doubling scenario results from a multimodel ensemble (9) simulating changes between 2000 and 2050 . Historical relationships in observed precipitation (10) are used to assess the probable impacts of the warming Indian (3) and eastern Pacific (4) Oceans.

9. G. A. Meehl et al., Bull. Am. Meteorol. Soc.; 10.1175/BAMS-88-9-1383.

10. R. F. Adler et al., J. Hydrometeor. 4, 1147 (2003). 